\title{
The Effects of Emotional Intelligence on Interpersonal Facilitation of Managers and Supervisors: Empirical Findings from Public Sector Enterprises in Kerala
}

\author{
Jils Baby Emmanue*, Santhosh. P. Thampi \\ School of Management and Business Studies, Mahatma Gandhi University, India
}

Copyright $(2016$ by authors, all rights reserved. Authors agree that this article remains permanently open access under the terms of the Creative Commons Attribution License 4.0 International License

\begin{abstract}
Research and discussions of EI predicted the possibility of the linkage between Emotional Intelligence skills and interpersonal facilitation. This study was conducted to examine empirically the extent to which Emotional Intelligence contributes to the interpersonal behaviours of managers and supervisors in Public Sector Enterprises in Kerala. The sample comprised of 500 respondents of which 243 were Managers and 257 were Supervisors in Public Sector Enterprises in Kerala. The data were analysed using SPSS 21 in which tools such as ANOVA, Correlation and Regression were applied. The results indicated that there is highly significant and positive relationship between Emotional Intelligence and interpersonal facilitation of managers and supervisors of Public Sector Enterprises in Kerala.
\end{abstract}

Keywords Emotional Intelligence, Interpersonal Facilitation, Public Sector Enterprises, Managers and Supervisors

\section{Introduction}

According to Dulewicz and Higgs Emotional Intelligence is about knowing what you are feeling, and being able to motivate yourself to get jobs done. It is sensing what others are feeling and handling relationships effectively ${ }^{[3]}$. Emotions drive behaviours, and an individual's ability to consider the potential overwhelming importance his or her own emotions may have on decision making is important. . A major factor in career success and personal satisfaction is our ability and willingness to establish and maintain healthy interpersonal interactions. Most professionals spend at least a third of their life at work. . If this time is to be used productively, they need to feel that the workplace is somewhere they want to be.

Any organization wishing to thrive through change must make the choice to promote, and allow employee expressions of Emotional Intelligence (EI) said by Hunton and Robertson ${ }^{[9]}$. Emotional Intelligence is all about being able to interact with other people; using our own emotions in harmony with others' emotions to create a desired outcome. An individual who has the ability to recognize and manage his emotions, develop care and concern for others, make responsible decisions, establish positive relationships and handle challenging situations effectively.

Interpersonal facilitation is defined by Van Scotter, J. R. and Motowidlo, S.J as the extent to which a worker helps others, contributes to their effective task performance, or helps maintain a social and psychological climate that facilitates accomplishment of the organizations' goals ${ }^{[19]}$. Each individual has certain positive qualities called strengths. Knowing how and when to combine these strengths changes the atmosphere in which they work. According to Keltner and Haidt Emotional Intelligence contribute to the quality of people's relationship at work because emotions serve communicative and social functions, conveying information about thoughts and intentions, and helping to coordinate social encounters ${ }^{[13]}$.

People skills are essential if a person wish to be successful in his dealings with others. This in turn affects his quality of life. The better skilled you are at communicating, the more likely you are to have reasonable relationships with people. Each organisation has a different way of doing things. Employees need to be able to tune in to the way of talking and acting so as to get the best out of workplace relationships.

Emotional Intelligence espouses social awareness and belief in the symbiotic outcome of cooperating with others. Possessing these skills makes establishing good relationships with other people a whole lot easier. . If Emotional Intelligence and interpersonal facilitation of employees go hand in hand there arises a comfortable work environment. Effective communication and emotional self-control, as well as understanding and appreciating the differences in others are reflections of interpersonal intelligence. The present study made an attempt to examine the relationship between 
Emotional Intelligence and interpersonal facilitation of managers and supervisors in select public sector firms in Kerala.

\section{Review of Literature}

The notion of EI can be traced to Thorndike's $(1920)^{[18]}$ concept of social intelligence, Wechsler's (1940) [21] propositions of non-intellective abilities as well as Gardner's $(1983)^{[5]}$ conceptualisation of personal intelligence. However, the term of 'emotional intelligence' (EI) owes its origin to Salovey and Mayer $(1990)^{[17]}$. They originally defined Emotional Intelligence as the ability of an individual to monitor one "own and others emotions, to discriminate among the positive and negative effects of emotion and to use emotional information to guide one's thinking and actions. Then Emotional Intelligence has been popularized by Goleman $(1995,1998)^{[788]}$, the concept is derived from social intelligence (Johnson and Indvik, 1999) ${ }^{[11]}$.

Unlike abstract intelligence, which refers to the ability to understand and manipulate symbols, or concrete intelligence, social intelligence refers to the ability to understand and relate to people. According to the Goleman's Emotional Intelligence model he identifies four Emotional Intelligence domains and 19 associated competencies. These four domains are self-awareness, self-management, social competence and social management Mayer, Salovey and Pellitteri defined Emotional Intelligence as an individual's ability to accurately perceive reality so as to understand and regulate their own emotional responses as well as adapt and respond to others ${ }^{[14 \& 16]}$. This emerges as four interrelated social skills, grouped around knowledge, perception, regulation and general intelligence ${ }^{[14]}$. Leaving aside general intelligence, the other components relate to the individual's ability to manage their emotional response ${ }^{[8 \& 14]}$. Emotional perception allows individuals to respond congruently, as they recognize their own and others' emotional responses. Emotional regulation means individuals self-monitor the intensity and direction of their own and others' emotional responses, as Pelliteri ${ }^{[16]}$ highlights, allowing them to moderate negative emotional reactions and remain positive. Regulation, the third component, allows individuals to utilize their emotional knowledge to promote creativity and flexibility, social relations and maintain motivation. Mayer and Salovey [14] recommend this framework be operationalized in the following ways. First, individuals who understand their own emotions can more accurately identify their responses and so change if need be. Second, the intellectual use of emotions means individual's cognitive decisions are more acute, so they are better able to assimilate information, make judgments or be creative and solve problems. This suggests emotionally intelligent people are more self-aware regarding their strengths and limitations, and because of this they are claimed to be more confident, optimistic, flexible, innovative and comfortable with new ideas ${ }^{[2,7,8 \& 14]}$.
Mellers et al. ${ }^{[15]}$ concluded emotions people expect to experience or have experienced as a result of their decisions are important determinants of their current and future behavior. Winter and Kuiper ${ }^{[22]}$ noted individuals differ in systematic ways in how they experience emotions, how they differentiate among emotions and how much emotional information they can process. Emotions are inseparable from individuals and very often emotions determine individual behaviour, decision making styles and even relationships ${ }^{[20]}$

Fineman describes Emotional Intelligence as a way of recognizing, understanding and choosing how we think, feel and act. It shapes our interaction with others and our understanding of ourselves. It defines how and what we learn, it allows us to set priorities, it determines the majority of our daily actions ${ }^{[4]}$. Huy ${ }^{[10]}$ introduced the concept of emotional capability to capture an organization's ability to acknowledge, recognize, monitor, discriminate, and attend to its members' emotions, and it is manifested in the organization's norms and routines related to the feeling.

George described Emotional intelligence, as a component of interpersonal skill, aids in managing personal feelings along with the moods and emotions of others ${ }^{[6]}$. Jordan, Ashkanasy and Hartel found that Emotional Intelligence is different from personality in that it brings together a varied group of abilities which explain how people recognize and manage emotions ${ }^{[12]}$. In this study, it was found that Emotional Intelligence influences social interaction and relationship development more than that of traditional personality measures.

All these pioneering definitions lead to conclude that EI is important in shaping one's personality, behaviour, style, and abilities.

\section{Conceptual Frame Work}

Based on the literature findings, the conceptual framework was constructed to show the relationship between independent variable (Emotional Intelligence) and dependent variable (Interpersonal facilitation).

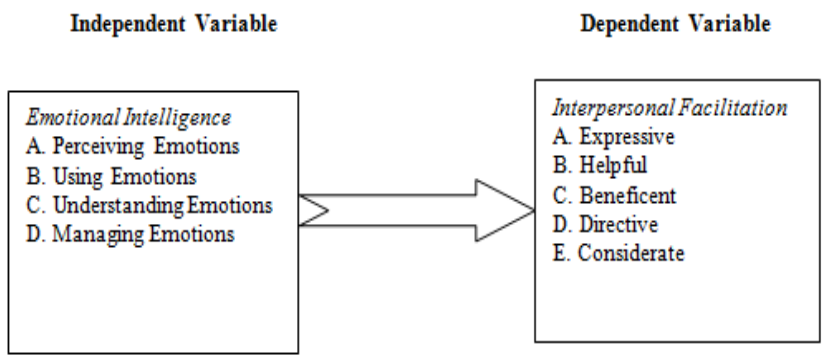

Figure 1. Conceptual frame work

Emotional Intelligence (EI) involves a set of skills that define how effectively you perceive, understand, express, reason with and manage your own and others feelings in a professional and effective manner. Under this major variable, four factors were used as minor variables. They are the ability to perceive emotions, ability to use emotions, ability 
to understand emotions and ability to manage emotions. Perceiving emotions refers to the capacities and abilities of recognizing and identifying emotions in others, in addition to biological and physiological processes involved. Using emotions refers to the capacity of the emotions to enter into and guide the cognitive system and promote thinking. Understanding emotions encompasses the ability to be sensitive to slight variations between emotions, and the ability to recognize and describe how emotions evolve over time. Managing emotions is the ability to regulate emotions in both ourselves and in others. Therefore, the emotionally intelligent person can harness emotions, even negative ones, and manage them to achieve intended goals.

Interpersonal facilitation pertains to interpersonally oriented behaviors that contribute to organizational goal attainment. Interpersonal facilitation is influenced by sub factors such as expressive behaviour, willingness to help, altruistic character, guiding others in the right direction and consideration of others.

\section{Research Methodology}

\subsection{Objectives of the Study}

The primary objective of this study is to describe the relationship between Emotional Intelligence and interpersonal facilitation of Managers and Supervisors in Public sector firms in Kerala. The objectives of the study include:

i. To establish the effect of demographic variables on Emotional Intelligence factor.

ii. To give suggestions to attain better interpersonal facilitation of managers and supervisors through improved Emotional Intelligence.

\subsection{Hypotheses}

H1: There is no significant difference between age and Emotional Intelligence of managers and supervisors.

$\mathrm{H} 2$ : There is no significant difference between gender and Emotional Intelligence of managers and supervisors.
H3: There is no significant difference between total service and Emotional Intelligence of managers and supervisors.

H4: There is no significant difference between qualification and Emotional Intelligence of managers and supervisors.

H5: There is no significant relationship between Emotional Intelligence factors and interpersonal facilitation factors.

\subsection{Variables}

From the review of literature the following variables were identified for the study. Emotional Intelligence factors include perceiving emotions, using emotions, understanding emotions and managing emotions. Interpersonal facilitation factors include expressive, helpful, beneficent, directive, and considerate behaviours of a person.

\subsection{Research Design}

A descriptive research approach was adopted for this study, in order to satisfy the research objectives. Primary and secondary data were used for this study. To obtain the primary data, a self-administered questionnaire was used. Journal articles, books and magazines were used in order to obtain the secondary data. This research design describes the state of affairs as it exists at present.

\subsection{Sample and Data Collection}

The target population for this investigation included respondents from Public Sector Enterprises in Kerala. Data were collected from 243 managers and 257 supervisors of Public Sector Enterprises with the help of a structured questionnaire. Public Sector Enterprises were selected from three regions (northern region, central region and southern region) of Kerala keeping in mind the number of managers and supervisors working in the firms. Judgment sampling was used to select the respondents from selected firms. The following table summarises the identification of Public Sector Enterprises. 
Table 1. Sample Selection

\begin{tabular}{|c|c|c|c|c|c|c|}
\hline Region & Enterpris & & No. of firms & Population & $\begin{array}{l}\text { Enterprises } \\
\text { selected }\end{array}$ & $\begin{array}{c}\text { No.of } \\
\text { respond-ents }\end{array}$ \\
\hline \multirow{8}{*}{ South } & \multirow{4}{*}{ Manufacturing } & \multirow{2}{*}{ Profit } & \multirow{2}{*}{13} & Managers-589 & \multirow{2}{*}{1} & 21 \\
\hline & & & & Supervisors-761 & & 27 \\
\hline & & \multirow{2}{*}{ Loss } & \multirow{2}{*}{11} & Managers-182 & \multirow{2}{*}{1} & 7 \\
\hline & & & & Supervisors-690 & & 25 \\
\hline & \multirow{4}{*}{ Service } & \multirow{2}{*}{ profit } & \multirow{2}{*}{24} & Managers-4275 & \multirow{2}{*}{1} & 154 \\
\hline & & & & Supervisors-1328 & & 48 \\
\hline & & \multirow{2}{*}{ Loss } & \multirow{2}{*}{14} & Managers-392 & \multirow{2}{*}{1} & 14 \\
\hline & & & & Supervisors-2169 & & 78 \\
\hline \multirow{8}{*}{ Central } & \multirow{4}{*}{ Manufacturing } & \multirow{2}{*}{ Profit } & \multirow{2}{*}{9} & Managers-315 & \multirow{2}{*}{1} & 12 \\
\hline & & & & Supervisors-367 & & 13 \\
\hline & & \multirow{2}{*}{ Loss } & \multirow{2}{*}{7} & Managers-150 & \multirow{2}{*}{1} & 6 \\
\hline & & & & Supervisors- 188 & & 7 \\
\hline & \multirow{4}{*}{ Service } & \multirow{2}{*}{ profit } & \multirow{2}{*}{3} & Managers-610 & \multirow{2}{*}{1} & 22 \\
\hline & & & & Supervisors-1277 & & 46 \\
\hline & & \multirow{2}{*}{ Loss } & \multirow{2}{*}{5} & Managers-114 & \multirow{2}{*}{1} & 4 \\
\hline & & & & Supervisors-272 & & 10 \\
\hline \multirow{6}{*}{ North } & \multirow{4}{*}{ Manufacturing } & \multirow{2}{*}{ Profit } & \multirow{2}{*}{2} & Managers-24 & & 1 \\
\hline & & & & Supervisors-17 & 1 & 1 \\
\hline & & Loss & 4 & Managers-84 & 1 & 3 \\
\hline & & Loss & 4 & Supervisors-34 & 1 & 1 \\
\hline & Service & profit & nil & & & \\
\hline & Service & Loss & nil & & & \\
\hline Total & & & 92 & 13838 & 10 & 500 \\
\hline
\end{tabular}

\subsection{Questionnaire}

The questionnaire used for this study consists of three sections. Section A was intended to collect the demographic data of the respondents. Section B and C consist of statements related to Emotional Intelligence and interpersonal facilitation factors. A five point Likert scale was used to record the response. The study compared the effect of Emotional Intelligence on interpersonal facilitation of managers and supervisors. Thirty four close ended items have been used to measure EI variable. Cronbach's alpha revealed that overall reliability of this variable is 0.914 . Fifteen close ended items have been used to measure the variable interpersonal facilitation. Cronbach's alpha revealed that overall reliability of this variable is 0.760 .

Average Variance Extracted (AVE) is an important measure of discriminant validity. The AVE value for the study variable emotional intelligence is 0.78 and Interpersonal facilitation is 0.80 . For average variance extracted, the loadings should be equal to 0.50 . Here all constructs have normal values.

Questionnaire was administered directly to the respondents.624 questionnaires were distributed and only 582 were returned. From this 500 completed questionnaires were taken for the study.

\subsection{Instruments and Measures}

Descriptive statistics were calculated. Babbie, Earl R. ${ }^{[1]}$ stated that descriptive statistics are used to describe the basic features of the data in a study. They provide simple summaries about the sample and the measures. Together with simple graphics analysis, they form the basis of virtually every quantitative analysis of data. Specifically descriptive statistics such as frequency distribution were calculated to summarize the sample data distribution. In order to analyse the data SPSS 21 was used. To find out the relationship between the variables of the study, Pearson's correlation analysis; Regression; and ANOVAs were used.

\section{Analysis and Interpretation}

\subsection{Demographic Features of Respondents}

Table 2. Demographic Features

\begin{tabular}{|c|c|c|}
\hline Characteristics & Frequency & Percent \\
\hline Agegroup & & 15 \\
$<30$ & 187 & 37.4 \\
$31-40$ & 138 & 27.6 \\
$41-50$ & 100 & 20 \\
$51-60$ & & \\
\hline Gender & 370 & 74 \\
Male & 130 & 26 \\
Female & 257 & 51.4 \\
\hline Designation & 243 & 48.6 \\
Supervisors & & 23 \\
Managers & 115 & 38 \\
\hline Total Service & 190 & 37 \\
$<10$ & 185 & 2 \\
$11-20$ & 10 & \\
$21-30$ & & 34.6 \\
$>30$ & 173 & 40.6 \\
\hline Qualification & 203 & 24.8 \\
\hline UG & 124 & \\
PG & & 23 \\
\hline
\end{tabular}

$74 \%$ of the respondents are male. Highest percentage of respondents $(37.4 \%)$ belongs to the age group of 31 to 40 . $51.4 \%$ of respondents belongs to the supervisory category. 
$38 \%$ of the respondents has 11 to 20 years of service and another $37 \%$ has 21 to 30 years of service. Educational qualification of $40.6 \%$ of the respondents is post-graduation.

\subsection{Relationship between Emotional Intelligence and Age Group of Respondents}

In order to find out the relationship between Emotional Intelligence factors; and age group of managers and supervisors, one way ANOVA was performed.

$\mathrm{H}_{0}$ : There is no significant relationship between age and Emotional Intelligence of managers and supervisors.

$\mathrm{H}_{1}$ : There is significant relationship between age and Emotional Intelligence of managers and supervisors.

From the table 3 it is clear that the $p$ value is less than .05 for 'perceiving emotions', 'using emotions' and 'understanding emotions' and hence $\mathrm{H}_{0}$ is rejected. Thus there is significant relationship exist between age group of managers and supervisors and Emotional Intelligence factors of perceiving emotions, using emotions and understanding emotions.

\subsection{Relationship between Emotional Intelligence and Gender of Respondents}

$\mathrm{H}_{0}$ : There is no significant relationship between gender and Emotional Intelligence of managers and supervisors.

$\mathrm{H}_{1}$ : There is significant relationship between gender and Emotional Intelligence of managers and supervisors.

The table shows that $\mathrm{p}$ value is greater than $.05 . \mathrm{H}_{0}$ is accepted. Hence there is no significant relationship exist between gender of managers and supervisors and the factors of Emotional Intelligence.

Table 3. ANOVA

\begin{tabular}{|c|c|c|c|c|c|c|}
\hline & & Sum of Squares & df & Mean Square & $\mathrm{F}$ & Sig. \\
\hline \multirow{3}{*}{ Perceiving emotions } & Between Groups & 13.958 & 3 & 4.653 & 4.110 & .007 \\
\hline & Within Groups & 561.479 & 496 & 1.132 & & \\
\hline & Total & 575.438 & 499 & & & \\
\hline \multirow{3}{*}{ Using emotions } & Between Groups & 11.513 & 3 & 3.838 & 2.106 & .099 \\
\hline & Within Groups & 903.954 & 496 & 1.822 & & \\
\hline & Total & 915.467 & 499 & & & \\
\hline \multirow{3}{*}{ Understanding emotions } & Between Groups & 12.354 & 3 & 4.118 & 3.594 & .014 \\
\hline & Within Groups & 568.316 & 496 & 1.146 & & \\
\hline & Total & 580.669 & 499 & & & \\
\hline \multirow{3}{*}{ Managing emotions } & Between Groups & 10.099 & 3 & 3.366 & 2.010 & .112 \\
\hline & Within Groups & 830.847 & 496 & 1.675 & & \\
\hline & Total & 840.946 & 499 & & & \\
\hline
\end{tabular}

Table 4. ANOVA

\begin{tabular}{|c|c|c|c|c|c|c|}
\hline & & Sum of Squares & $\mathrm{df}$ & Mean Square & $\mathrm{F}$ & Sig. \\
\hline \multirow{3}{*}{ Perceiving emotions } & Between Groups & 1.770 & 1 & 1.770 & 1.537 & .216 \\
\hline & Within Groups & 573.667 & 498 & 1.152 & & \\
\hline & Total & 575.438 & 499 & & & \\
\hline \multirow{3}{*}{ Using emotions } & Between Groups & .217 & 1 & .217 & .118 & .731 \\
\hline & Within Groups & 915.250 & 498 & 1.838 & & \\
\hline & Total & 915.467 & 499 & & & \\
\hline \multirow{3}{*}{ Understanding emotions } & Between Groups & .374 & 1 & .374 & .321 & .571 \\
\hline & Within Groups & 580.295 & 498 & 1.165 & & \\
\hline & Total & 580.669 & 499 & & & \\
\hline \multirow{3}{*}{ Managing emotions } & Between Groups & .742 & 1 & .742 & .440 & .508 \\
\hline & Within Groups & 840.204 & 498 & 1.687 & & \\
\hline & Total & 840.946 & 499 & & & \\
\hline
\end{tabular}




\subsection{Relationship between Emotional Intelligence and Designation of Respondents}

$\mathrm{H}_{0}$ : There is no significant relationship between designation and Emotional Intelligence of managers and supervisors. $\mathrm{H}_{1}$ : There is significant relationship between designation and Emotional Intelligence of managers and supervisors.

Table 5. ANOVA

\begin{tabular}{|c|c|c|c|c|c|c|}
\hline & & Sum of Squares & $\mathrm{df}$ & Mean Square & $\mathrm{F}$ & Sig. \\
\hline \multirow{3}{*}{ Perceiving emotions } & Between Groups & .120 & 1 & .120 & .104 & .747 \\
\hline & Within Groups & 575.317 & 498 & 1.155 & & \\
\hline & Total & 575.438 & 499 & & & \\
\hline \multirow{3}{*}{ Using emotions } & Between Groups & .454 & 1 & .454 & .247 & .620 \\
\hline & Within Groups & 915.013 & 498 & 1.837 & & \\
\hline & Total & 915.467 & 499 & & & \\
\hline \multirow{3}{*}{ Understanding emotions } & Between Groups & 3.975 & 1 & 3.975 & 3.433 & .065 \\
\hline & Within Groups & 576.694 & 498 & 1.158 & & \\
\hline & Total & 580.669 & 499 & & & \\
\hline \multirow{3}{*}{ Managing emotions } & Between Groups & .062 & 1 & .062 & .037 & .848 \\
\hline & Within Groups & 840.884 & 498 & 1.689 & & \\
\hline & Total & 840.946 & 499 & & & \\
\hline
\end{tabular}

The table shows that $\mathrm{p}$ value is less than .05 for the factor 'understanding emotions'. For other factors $\mathrm{p}$ value is greater than .05 and hence $\mathrm{H}_{0}$ is accepted. Hence there is no significant relationship exist between designation of respondents and Emotional Intelligence.

\subsection{Relationship between Emotional Intelligence and Total Service of Respondents}

$\mathrm{H}_{0}$ : There is no significant relationship between total service and Emotional Intelligence of managers and supervisors.

$\mathrm{H}_{1}$ : There is significant relationship between total service and Emotional Intelligence of managers and supervisors.

Table 6. ANOVA

\begin{tabular}{|c|c|c|c|c|c|c|}
\hline & & Sum of Squares & $\mathrm{df}$ & Mean Square & $\mathrm{F}$ & Sig. \\
\hline \multirow{3}{*}{ Perceiving emotions } & Between Groups & 11.378 & 3 & 3.793 & 3.335 & .019 \\
\hline & Within Groups & 564.059 & 496 & 1.137 & & \\
\hline & Total & 575.438 & 499 & & & \\
\hline \multirow{3}{*}{ Using emotions } & Between Groups & 11.345 & 3 & 3.782 & 2.075 & .103 \\
\hline & Within Groups & 904.122 & 496 & 1.823 & & \\
\hline & Total & 915.467 & 499 & & & \\
\hline \multirow{3}{*}{ Understanding emotions } & Between Groups & 14.783 & 3 & 4.928 & 4.319 & .005 \\
\hline & Within Groups & 565.887 & 496 & 1.141 & & \\
\hline & Total & 580.669 & 499 & & & \\
\hline \multirow{3}{*}{ Managing emotions } & Between Groups & 7.480 & 3 & 2.493 & 1.484 & .218 \\
\hline & Within Groups & 833.466 & 496 & 1.680 & & \\
\hline & Total & 840.946 & 499 & & & \\
\hline
\end{tabular}

From the above table it is clear that the p value is less than .05 for 'perceiving emotions' and 'understanding emotions' and hence $\mathrm{H}_{0}$ is rejected. Hence there is significant relationship exist between years of service of managers and supervisors and Emotional Intelligence factors of perceiving emotions and understanding emotions.

\subsection{Relationship between Emotional Intelligence and Qualification of Respondents}

$\mathrm{H}_{0}$ : There is no significant relationship between qualification and Emotional Intelligence of managers and supervisors.

$\mathrm{H}_{1}$ : There is significant relationship between qualification and Emotional Intelligence of managers and supervisors. 
Table 7. ANOVA

\begin{tabular}{|c|c|c|c|c|c|c|}
\hline & & Sum of Squares & df & Mean Square & $\mathrm{F}$ & Sig. \\
\hline \multirow{3}{*}{ Perceiving emotions } & Between Groups & 3.483 & 2 & 1.741 & 1.513 & .221 \\
\hline & Within Groups & 571.955 & 497 & 1.151 & & \\
\hline & Total & 575.438 & 499 & & & \\
\hline \multirow{3}{*}{ Using emotions } & Between Groups & 5.807 & 2 & 2.903 & 1.586 & .206 \\
\hline & Within Groups & 909.660 & 497 & 1.830 & & \\
\hline & Total & 915.467 & 499 & & & \\
\hline \multirow{3}{*}{ Understanding emotions } & Between Groups & 1.141 & 2 & .571 & .489 & .613 \\
\hline & Within Groups & 579.528 & 497 & 1.166 & & \\
\hline & Total & 580.669 & 499 & & & \\
\hline \multirow{3}{*}{ Managing emotions } & Between Groups & .261 & 2 & .131 & .077 & .926 \\
\hline & Within Groups & 840.685 & 497 & 1.692 & & \\
\hline & Total & 840.946 & 499 & & & \\
\hline
\end{tabular}

Here also the $\mathrm{p}$ value is greater than .05 and $\mathrm{H}_{0}$ is accepted. Hence there is no significant relationship exist between qualification and Emotional Intelligence of respondents.

\subsection{Relationship between Emotional Intelligence and Interpersonal Facilitation.}

Bivariate analysis has been carried out in order to study the relationship between Emotional Intelligence and Interpersonal Facilitation. For bivariate analysis both correlation and regression were used.

Hypothesis was formulated to establish the association and the nature of relationship between Interpersonal facilitation and the four dimensions of Emotional Intelligence.

$\mathrm{H}_{0}$ : There is no significant relationship between Emotional Intelligence factors and interpersonal facilitation.

$\mathrm{H}_{1}$ : There is significant relationship between Emotional Intelligence factors and interpersonal facilitation.

Table 8. Correlations

\begin{tabular}{|c|c|c|c|c|c|c|}
\hline & & $\begin{array}{c}\text { Perceiving } \\
\text { emotions }\end{array}$ & $\begin{array}{c}\text { Using } \\
\text { emotions }\end{array}$ & $\begin{array}{c}\text { Understanding } \\
\text { emotions }\end{array}$ & $\begin{array}{c}\text { Managing } \\
\text { emotions }\end{array}$ & $\begin{array}{c}\text { Interpersonal } \\
\text { facilitation }\end{array}$ \\
\hline \multirow{3}{*}{ Perceiving emotions } & Pearson Correlation & 1 & $.287^{* *}$ & $.217^{* *}$ & $.258^{* *}$ & $.594^{* *}$ \\
\hline & Sig. (2-tailed) & & .000 & .000 & .000 & .000 \\
\hline & $\mathrm{N}$ & 500 & 500 & 500 & 500 & 500 \\
\hline \multirow{3}{*}{ Using emotions } & Pearson Correlation & $.287^{* *}$ & 1 & $.179^{* *}$ & -.011 & $.468^{* *}$ \\
\hline & Sig. (2-tailed) & .000 & & .000 & .806 & .000 \\
\hline & $\mathrm{N}$ & 500 & 500 & 500 & 500 & 500 \\
\hline \multirow{3}{*}{ Understanding emotions } & Pearson Correlation & $.217^{* *}$ & $.179^{* *}$ & 1 & $.202^{* *}$ & $.451^{* *}$ \\
\hline & Sig. (2-tailed) & .000 & .000 & & .000 & .000 \\
\hline & $\mathrm{N}$ & 500 & 500 & 500 & 500 & 500 \\
\hline \multirow{3}{*}{ Managing emotions } & Pearson Correlation & $.258^{* *}$ & -.011 & $.202^{* *}$ & 1 & $.382^{* *}$ \\
\hline & Sig. (2-tailed) & .000 & .806 & .000 & & .000 \\
\hline & $\mathrm{N}$ & 500 & 500 & 500 & 500 & 500 \\
\hline \multirow{3}{*}{ Interpersonal facilitation } & Pearson Correlation & $.594^{* *}$ & $.468^{* *}$ & $.451^{* *}$ & $.382^{* *}$ & 1 \\
\hline & Sig. (2-tailed) & .000 & .000 & .000 & .000 & \\
\hline & $\mathrm{N}$ & 500 & 500 & 500 & 500 & 500 \\
\hline
\end{tabular}

**. Correlation is significant at the 0.01 level (2-tailed). 
Analysis of the data obtained from the Pearson correlation analysis, indicates that interpersonal facilitation is positively correlated with the four components of Emotional Intelligence. The association is significant at the 0.01 level, which indicates that the association is highly significant and the relationship is positive. The correlation analysis also reveals that the association is highly significant and the strength of the association between interpersonal facilitation and the four component of Emotional Intelligence are very strong. The value of coefficient ( $r$ ) determines the strength of the association and is very strong and positive between perceiving emotions, using emotions, understanding emotions and interpersonal facilitation (.594) (.468), (.451) respectively. However as compared to perceiving emotions, using emotions and understanding emotions, the association is moderately strong among managing emotions and interpersonal facilitation. The value is 0.382 .

From the table given above, it is seen that, the value of $\mathrm{p}$ is less than 0.01.Therefore $\mathrm{H}_{0}$ is rejected. Hence, there is significant relationship between Emotional Intelligence and interpersonal facilitation.

\section{Regression Analysis}

Table 9. Model Summary

\begin{tabular}{|c|c|c|c|c|}
\hline Model & $\mathrm{R}$ & $\mathrm{R}$ Square & $\begin{array}{c}\text { Adjusted R } \\
\text { Square }\end{array}$ & $\begin{array}{c}\text { Std. Error of the } \\
\text { Estimate }\end{array}$ \\
\hline 1 & $.764^{\mathrm{a}}$ & .584 & .581 & .64267 \\
\hline
\end{tabular}

a. Predictors: (Constant), managing emotions, using emotions, understanding emotions, perceiving emotions

The table illustrates that value of $\mathrm{R}$ square is .584 which is equal to $58.4 \%$. This means that independent variable (Emotional Intelligence of managers and supervisors) is accounting for $58.4 \%$ of variation in the dependent variable (interpersonal facilitation).

Table 10. ANOVA $^{\mathrm{a}}$

\begin{tabular}{|c|c|c|c|c|c|c|}
\hline \multicolumn{2}{|c|}{ Model } & $\begin{array}{c}\text { Sum of } \\
\text { Squares }\end{array}$ & df & $\begin{array}{c}\text { Mean } \\
\text { Square }\end{array}$ & F & Sig. \\
\hline \multirow{3}{*}{1} & Regression & 287.160 & 4 & 71.790 & 173.818 & $.000^{\mathrm{b}}$ \\
\cline { 2 - 7 } & Residual & 204.444 & 495 & .413 & & \\
\cline { 2 - 7 } & Total & 491.604 & 499 & & & \\
\hline
\end{tabular}

a. Dependent Variable: interpersonal facilitation

b. Predictors: (Constant), managing emotions, using emotions, understanding emotions, perceiving emotions

$\mathrm{F}(4,495)=173.818 ; \mathrm{P}<0.01$

From the table given above, it is seen that, the value of $p$ is less than 0.01 . Hence the overall effect of this independent variable (Emotional intelligence) is highly significant. Therefore, the study can generalise the results of sample to predict for the entire population.

\section{Discussion}

The study analysed the effects of demographical variables on emotional intelligence. The test results show that there is a significant relationship between the demographical variables (such as age and total service) of managers and supervisors; and their Emotional Intelligence. But the variables like gender, designation and qualification of managers and supervisors do not have significant relationship on emotional intelligence. Emotional Intelligence has four elements: perceiving emotions, using emotions, understanding emotions, and managing emotions. Emotional Intelligence helps the managers and supervisors to create a positive environment so that people are happy working together. The result of correlation coefficient and regression revealed that Emotional Intelligence of managers and supervisors is significantly related with interpersonal facilitation in an organization. The study results provide sufficient evidence for the fact that Emotional Intelligence, measured as a set of abilities is associated positively with interpersonal behaviours. By having clear understanding of Emotional Intelligence, managers and supervisors in Public Sector Enterprises can increase the job commitment, loyalty and growth of organization.

\subsection{Practical Implications of the Study}

From the study it is revealed that there is strong correlation between Emotional Intelligence and interpersonal facilitation of managers and supervisors in public sector firms in Kerala. By developing Emotional Intelligence skills, managers and supervisors will understand that their thoughts and feelings are being appreciated and accepted. Success of managers and supervisors is not only based on reaching the targets, but also on the development of his or her team and establishing good relationships. It is also desirable that since Emotional Intelligence has significant impacts on interpersonal facilitation, the managers and supervisors should be coached on Emotional Intelligence skills.

\subsection{Recommendations for Future Studies}

Further studies can include larger and broader samples that are more representative of the population, examining other factors of workplace outcomes such as work attitude, performance management, organisation citizenship behaviour, employee motivation, decision making process, stress management etc. Employees at different levels in the organisation should be included in the study.

\section{Conclusions}

To be an effective person at work, employees should be able to demonstrate problem solving ability, decision making aptitude, clear communication skills and be proficient at managing workplace relationships. Emotionally intelligent people will have awareness of situations pertaining to themselves and beyond their own personal perspectives. Results of the study strongly support that by developing Emotional Intelligence skills, employees can improve personal productivity at work and attain a high level of quality relationships both inside and outside the job. These 
employees show a healthy awareness of what is going on around him both physically and psychologically. Hence PSEs should take initiatives to improve the EI of their managers and supervisors to have better interpersonal facilitation, which will have an effect on improving performance.

\section{REFERENCES}

[1] Babbie, Earl R. (2009). The Practice of Social Research (12th ed.). Wadsworth. pp. 436-440

[2] Bellack JP. 1999. Emotional intelligence: a missing ingredient? Journal of Nursing Education 38(1): 3-4

[3] Dulewicz, V., and Higgs, M. (2000). Emotional intelligence, a review and evaluation study. Journal of Management Psychology, 15(4), 341-372.

[4] Fineman, S. (1993). Organizations as emotional arenas. In S. Fineman (Ed.), Emotion in organizations (pp. 9-35). London: Sage

[5] Gardner, H. (1983). Multiple intelligences: the theory in practice. NY: Basic Books.

[6] George, J.M.(2000).Emotions and leadership.The role of emotional intelligence. Human Relations,53(8), 1027- 1044.

[7] Goleman, D. (1995). Emotional intelligence. New York: Bantam Books.

[8] Goleman, D. (1998). Working with emotional intelligence. New York: Bantam Books

[9] Hunton JE, TW Hall and KH Price, 1998. "The Value of Voice in Participative Decision-making". Journal of Applied Psychology 183 No 5, pp 788-797.

[10] Huy, Q.N. (1999), "Emotional capability, Emotional Intelligence and radical change", Academy of Management Review, Vol. 24 No. 2, pp. 325-45.

[11] Johnson PR, Indvik J. 1999. Organizational benefits of having emotionally intelligent managers and employees. Journal of Workplace Learning 11(3): 84-88.

[12] Jordan, P.J., Ashkanasy, N.M., Hartel, C.E.J. and Hooper, G. (2002), "Workgroup emotional intelligence: scale development and relationship to team process effectiveness and goal focus", Human Resource Management review, Vol. 12, pp. 195-214.

[13] Keltner. D \& Haidt. J. (2001). Social functions of emotions. In T.J. Mavne and G.A. Bonanno (eds): Emotions: Current issues and future directions. New York.pp192-213.

[14] Mayer, J.D. \& Salovey, P. What is emotional intelligence: Implications for educators. In P. Salovey and D. Sluyter (Eds), Emotional development,emotional literacy, and emotional intelligence. New York: Basic Books,1997, pp. 3-31.

[15] Mellers, B.A., Schwartz, A. and Ritov, I. (1999), "Emotion-based choice", Journal of Experimental Psychology: General, Vol. 128, pp. 1-14.

[16] Pelliteri, J. (2002). The relationship between Emotional Intelligence and ego defense mechanisms. Journal of Psychology, 136, 182-194.

[17] Salovey, P. \& Mayer, J. D. (1990). Emotional Intelligence. Imagination, Cognition and Personality. 9 (3), pp.185-211.

[18] Thorndike, E. L. (1920). Intelligence and its uses. Harper's Magazine. 140, pp.227-235.

[19] Van Scotter. J.R \& Motowidlo, S. J. (1996). Interpersonal Facilitation and Job dedication as separate facets of contextual performance. Journal of Applied Psychology, 81, 525-531.

[20] Watson, P. J., Ghorbani, N., Davison, H. K., Bing, M. N., Hood, R. W., Jr., \& Ghramaleki, A. F. (2002). Negatively reinforcing personal extrinsic motivations: Religious orientation, inner awareness, and mental health in Iran and the United States. The International Journal for the Psychology of Religion, 12, 255-276.

[21] Wechsler, D. (1940). Non-intellective factors in general intelligence. Psychological Bulletin, 37, 444-445.

[22] Winter, K.A. and Kuiper, N.A. (1997), "Individual differences in the experience of emotions",Clinical Psychology Review, Vol. 17, pp. 791-821. 